\title{
Incentives and limitations of employment policies on retirement transitions
}

\author{
Robert L. Clark ${ }^{1 \star}$ and Joseph P. Newhouse ${ }^{2}$ \\ ${ }^{1}$ Professor, Department of Economics, North Carolina State University and ${ }^{2}$ John D. MacArthur Professor of Health Policy \\ and Management, Harvard Kennedy School, Harvard University, Harvard Medical School, Department of Health Care \\ Policy, Harvard University; Harvard T.H. Chan School of Public Health, Department of Health Policy and Management, \\ Harvard University \\ *Corresponding author. E-mail: robert_clark@ncsu.edu
}

(First published online 26 February 2019)

JEL Codes: J23; J26; J32

As the population ages and life expectancy at older ages increase, it becomes more challenging for individuals, firms, and governments to finance adequate living standards in retirement. Working longer is an important option that must be considered if well-being in retirement is to be sustained. The papers in this Special Issue of the Journal of Pension Economics and Finance explore various aspects of the transition from career employment to complete retirement. The research covers a broad range of topics including comparing retirement transitions in the public and private sectors, individual incentives that influence retirement timing, return-to-work policies adopted by many public employers, and the management of wealth before and during retirement. The articles also consider how many individuals move from career jobs to new employment and then to complete retirement. In addition, the research focuses on work incentives of employer-provided pensions and health plans, Social Security, and government sponsored health plans, and also how provisions of these plans alter the transition to retirement.

The articles are grouped into three areas. The first set of four articles examines the retirement transition and the importance of return-to-work policies, pension characteristics, and Social Security provisions influencing labor market behavior. Three of the studies focus on public school teachers and other public sector employees, while the fourth compares retirement transitions of private and public sector workers. The second set comprises two papers exploring changes in health insurance plans, how these plans are financed, and the impact of plan provisions on work and retirement decisions. The third set considers how financial market conditions influence economic well-being in retirement and contains three articles exploring how interest rates shape the choice of annuity options, saving decisions, and workers' ability to achieve their desired standard of living in retirement. These papers highlight the variety of paths that workers follow in transitioning from their full time career jobs to complete retirement, and they also show how these paths are influenced by employer retirement policies, Social Security, and financial market conditions.

\section{Retirement transitions: return to work policies, pensions, and Social Security provisions}

In contrast to most private sector pension plans, state and local pension plans in the United States embed strong economic incentives for career employees to leave employment and begin receiving pension benefits at relatively young ages. Given their relatively young retirement ages, many public sector retirees might like to return to work, either in their same job or in some other employment. Yet many government employers restrict their retirees from returning to work. In her article, 'Pension Reform 
and Return to Work Policies,' Maria Fitzpatrick describes these restrictions, the most common of which is to limit the number of hours retirees can work without loss of pension benefits. In other words, returning to work part-time is potentially acceptable, but returning to full-time can result in the loss of some or all pension benefits.

Such restrictions on post-retirement work can influence the timing of retirement as well as post-retirement work decisions. Fitzpatrick (2019) estimates the impact of return-to-work rules on retirement decisions and post-retirement labor supply using data from the Illinois Public School system and the Illinois Teacher Retirement system. She concludes that school personnel are sensitive to return-to-work rules: increases in the maximum permissible hours of post-retirement employment boost both retirement benefit collection and part-time work among retirees. As such, these employer policies appear to be binding on the labor supply decisions of some public sector employees.

Leslie Papke examines the sensitivity and timing of retirement decisions by public employees to key features of state pension plans in her paper 'Retirement Options and Outcomes for Public Employees.' Such features include benefit generosity, early and normal retirement eligibility requirements, and the gain in benefits from delaying retirement. Her analysis uses information on job histories from 12 waves of the Health and Retirement Study (HRS) to identify public employees and their retirement choices.

Papke (2019) employs a proportional hazard model with time-varying covariates to estimate the factors driving retirement ages. Her primary finding is that retirement is responsive to a number of program eligibility focal points; these include eligibility for benefit receipt, normally conditioned on age and service requirements. She also finds a decline in the probability of retirement, the larger the gain in pension wealth from continued work. These results for public employees are consistent with a larger literature on retirement decisions by private sector workers.

Public sector workers often leave their full-time career jobs (FCJ) younger than do their private sector counterparts, in part because defined benefit pension plans with strong early retirement incentives, are more common in the public sector. One might therefore expect work patterns after leaving the FCJ to differ between public and private sector workers. Surprisingly, however, Joseph Quinn, Kevin Cahill, and Michael Giandrea find that this is not the case using the first cohort of the Health and Retirement Survey (HRS). Their article, 'Transitions from Career Employment among Public and Private-Sector Workers,' the authors define three types of patterns following retirement from a FCJ: a bridge job, defined as a new job that may or may not be part time; phased retirement, which entails working $20 \%$ fewer hours at the career job; and re-entry, which involves returning to work after four or more years of non-work.

The authors' somewhat surprising conclusion is that the pattern of post-retirement work is broadly similar for both public and private sector workers. About half of both groups take a bridge job after leaving their FCJ, with re-entry after no work the next most common pattern. Phased retirement is the least common. To be sure, there are some differences between public and private sector workers. For instance, retirees from the public sector have a higher prevalence of part-time bridge employment, and public sector female retirees have a higher prevalence of phased retirement. Nevertheless, the overall picture is comparable.

Although many people assume Social Security coverage is universal, in fact, around $25 \%$ of public sector employees are not included in the US Social Security system. In 'The Role of Social Security in Retirement Timing: Evidence from a National Sample of Teachers,' Melinda Morrill and John Westall explore whether not being covered by Social Security affects retirement behavior of public school teachers, about $40 \%$ of whom are not covered by the system.

While other authors have examined how retirement responds to Social Security benefit levels at the intensive margin, Morrill and Westall (2019) are the first to evaluate whether retirement ages in the public sector are affected by eligibility for Social Security, on the extensive margin. The authors find that teachers do respond to the presence of Social Security. Prior to age 62, teachers that do participate in Social Security retire at about the same rate as those that do not. But at age 62, the first age of eligibility for Social Security benefits, teachers eligible for Social Security are about 4 percentage points 
more likely to retire than ineligible teachers. Moreover, they are notably more likely to retire at every subsequent age up to 70 other than 63 .

\section{Financing health plans and the impact on work and retirement}

Public and private employers often face difficult fiscal challenges associated with the cost of providing health care to active workers as well as retirees. The article by John Hsu, Joseph Newhouse, Lindsay Overhage, and Samuel Zuvekas entitled 'Impact of Fiscal Shocks on Retiree Health Plans and the Effect on Work and Retirement' examines how cities' financial health affects their ability to provide their workers with health insurance, as well as labor force and health effects in cities in fiscal difficulty. The authors' key indicator of financial distress is whether the city suffered a recent downgrade in the quality of its bond ratings.

The authors match 23 cities with downgrades to their credit ratings and 31 cities that maintained stable ratings to sampling units in the Medical Expenditure Panel Survey. Using a standard difference-in-difference analysis, the researchers find that, in the year of the downgrade and for the three subsequent years, employees' rate of separation fell by about half in the cities with downgrades.

Norma Coe (2019) examines a change in insurance plans offered Washington state employees in her article, 'Impact of Health Plan Reforms in Washington on Retirement Decisions.' Prior to 2016, the state had offered a menu of insurance plans that reimbursed providers on a fee-for-service basis; then starting in 2016, new plans were offered that shifted some financial risk toward provider groups using so-called value-based (as opposed to volume-based) insurance. This led the provider groups to reduce the use of services in these plans, so health insurance premiums charged to state employees for these plans were below those in the past. Nevertheless, the physician network from which patients could choose was narrower, because the providers taking financial risk sought to channel patients to themselves to better control service volume.

Coe (2019) studies the effect of this change in the menu of insurance plans on both health plan choice and labor force behavior. She finds that employees closer to retirement age were less likely to switch to the new plans, even when their prior physicians would have remained in network. She also finds that younger workers who signed up for the new product were less likely to leave state employment, but the new insurance product was associated with a decrease in the age of retirement.

\section{Managing retirement wealth}

The article by Robert Clark, Robert Hammond, and David Vanderweide entitled 'Navigating Complex Financial Decisions at Retirement: Evidence from Annuity Choices in Public Sector Pensions' analyzes the factors shaping annuity choices within the context of a public sector defined benefit pension plan. Using combined administrative records and survey data for state and local retirees in North Carolina, they explore the role of individual and household characteristics as well as risk preferences, time preferences, and financial literacy on whether a retiree selects a single life annuity or a joint and survivor annuity.

The authors describe the pricing of annuity options and show the impact of alternative interest rates on monthly benefits. Findings are consistent with predictions of which households might benefit most from each annuity option. An examination of retirees who chose different types of annuities reveals that different groups report very different levels of retirement well-being. All retirees report lower levels of retirement income security over time, with strong differences among those who chose different types of annuities.

In their paper entitled 'How Will Persistent Low Expected Returns Shape Household Behavior,' Vanya Horneff, Raimond Maurer, and Olivia S. Mitchell evaluate how retirement saving decisions will respond in an environment with persistently low interest rates and investment returns. In particular, lower real returns have profound impacts on work, retirement ages, saving, consumption, and investment behavior, which they illustrate using a calibrated realistic dynamic life cycle model. 
Results include the finding that workers will build up less wealth in their tax-qualified 401(k) accounts compared to the past, in a low expected return regime.

Their analysis also indicates that men and women optimally claim Social Security benefits later and work longer when expected real returns are low. Additionally, there is considerable heterogeneity in behavioral responses, with better-educated individuals being more sensitive to real interest rate changes. By contrast, the least-educated alter their behavior less. This result implies that wealth inequality will be compressed in an environment of persistent low expected returns.

In the article by Gila Bronstein, Jason Scott, John B. Shoven, and Sita Slavov entitled 'The Power of Working Longer,' the authors propose that many households believe they will have less income in retirement than they might wish. The authors evaluate the actions that households could take to enhance their retirement income, including working longer, saving more during one's working life, and obtaining a greater return on savings.

The authors conclude that the best way to boost retirement income is to work longer, echoing earlier research by Skinner (2007). They estimate that extending the worklife by only $3-6$ months has the same effect on annual post-retirement income as a one percentage point increase in labor earnings for 30 years. Their measure of working longer includes households delaying claiming of Social Security benefits, deferring drawdowns of other retirement assets, and the continuation of retirement saving.

\section{Conclusions}

This Special Issue of the Journal of Pension Economics and Finance examines several mechanisms to finance retirement, as well as ways in which employer and government policies affect labor force behavior at older ages. The analyses illuminate a variety of paths and labor supply options for individuals as they shift from FCJs into retirement, with the specific choice of paths driven by Social Security and pension characteristics, interest rates and returns to retirement saving, employer return-to-work provisions, and the availability of retiree health plans.

Clark et al. (2019) show that only 37\% of retirees surveyed three or more years post-retirement thought they had saved enough. Accordingly, as Bronshtein et al. (2019) argue, it may be critical for people to work longer, so as to enhance their retirement security. Quinn et al. (2019) report that working at a new job or continuing to work part-time in one's FCJ is reasonably common, for both public and private sector workers. Moreover, persistent low returns will, according to Horneff et al. (2019), lead to delayed retirement and lower wealth accumulations.

Yet as Fitzpatrick (2019) points out, some employers have policies that restrict the extent of work following retirement, as with teachers in Illinois. Such policies may well be preventing retired teachers and others from achieving their desired retirement income. And as Papke and Morrill and Westall (2019) show, many pension plans shape retirement ages by setting when workers become eligible to immediately receive a retirement benefit.

Health insurance costs are another major and uncertain expense for retirees in the United States, especially for those retiring before the age of 65 when they could be eligible for Medicare. While many younger retirees can purchase coverage from the Affordable Care Act's marketplaces, these plans are expensive in terms of premiums and cost sharing. Retirees from public sector jobs are especially subject to sticker shock when buying retiree health coverage, as their employers tend to have generous policies. Indeed, those generosity of those policies is a source of fiscal strain for many state and local governments. Coe (2019) reports on a reform in the state of Washington seeking to reduce public employer health care costs by shifting some financial risk toward health care providers. Additionally, Hsu et al. (2019) report that public sector employees of cities in fiscal difficulty are more likely to remain on the job to retain their active worker health insurance, compared to public sector workers in more fiscally stable cities.

In summary, the papers in this Special Issue of the JPEF offer interesting new evidence on retirement transitions in both the public and private sectors. Findings underscore the impact of pension benefits and health insurance as important drivers of the retirement decision. Additionally, 
employment policies and employee preferences shape retirees' work options, which in turn give older individuals the opportunity to delay full retirement.

Financial support. The papers in this Special Issue of the JPEF were first presented at an NBER Conference held in Jackson, WY August 10-11, 2018. The research and conference were supported by a grant from the Sloan Foundation.

\section{References}

Bronshtein G, Scott J, Shoven JB and Slavov S (2019) The power of working longer. Journal of Pension Economics and Finance this issue.

Clark R, Hammond R and Vanderweide D (2019) Navigating Complex financial decisions at retirement: evidence from annuity choices in public sector pensions. Journal of Pension Economics and Finance this issue.

Coe N (2019) Impact of health plan reforms in Washington on retirement decisions the state of Washington. Journal of Pension Economics and Finance this issue.

Fitzpatrick M (2019) Pension reform and return to work policies. Journal of Pension Economics and Finance this issue.

Horneff V, Maurer R and Mitchell OS (2019) How will persistent low expected returns shape household behavior. Journal of Pension Economics and Finance this issue.

Hsu J, Newhouse J, Overhage L and Zuvekas S (2019) Impact of fiscal shocks on retiree health plans and the effect on work and retirement. Journal of Pension Economics and Finance this issue.

Morrill MS and Westall J (2019) The role of social security in retirement timing: evidence from a national sample of teachers. Journal of Pension Economics and Finance this issue.

Papke L (2019) Retirement options and outcomes for public employees. Journal of Pension Economics and Finance this issue.

Quinn J, Cahill K, College B and Giandrea M (2019) Transitions from career employment among public and private-sector workers. Journal of Pension Economics and Finance this issue.

Skinner JS (2007) Are you sure you're saving enough for retirement? Journal of Economic Perspectives 21, 59-80.

Cite this article: Clark RL, Newhouse JP (2019). Incentives and limitations of employment policies on retirement transitions. Journal of Pension Economics and Finance 18, 495-499. https://doi.org/10.1017/S1474747219000039 